\title{
Kanban Systems in the Context of the Enterprise Systems
}

\author{
Livia Dana Beju ${ }^{1, *}$, and Stanislaw Legutko ${ }^{2}$ \\ 1"Lucian Blaga" University of Sibiu, Engineering Faculty, 550024 Sibiu, Romania \\ ${ }^{2}$ Poznan University of Technology, Institute of Mechanical Technology, Poznan, Poland
}

\begin{abstract}
Companies are under increasing pressure from customers, competitors, limited resources, etc. These conditions oblige companies to permanently improve their organizational structure and the activities of all system's flows. The paper analyses the types of Kanban systems, in the broader context of the enterprise systems. The most important reference architectures were analysed (with the emphasis on the modules dedicated to flow description) and the standards that allow the activity modelling of a manufacturing enterprises. Starting from this context, the paper describes three models of Kanban systems that are specific to companies with different information systems development. Models are: Push production with withdrawal Kanban; Pull production with withdrawal Kanban and production Kanban triggered by Kanban board; Pull production with withdrawal Kanban and production Kanban triggered by the dispatch to the customers. The models are graphically described using Value Stream Map (VMS) symbols. These models are useful in the development and improvement of production flows.
\end{abstract}

\section{Introduction}

Actual organizations are subject to increasing challenges due to the fast pace of scientific research, globalization, depletion of material resources, increasing customer expectations, etc. Under these conditions, companies must innovate but also focus on efficiency, productivity and quality. This can be done only by companies that have clear, efficient organizational structures, that can easily improve themselves. The current trends of extended, agile and virtual enterprises impose clear and efficient organizational structures and informational technologies.

Concepts such as the product life cycle management but also the development of the company's organizational structures on the basis of reference architectures have proven to be extremely efficient in optimizing companies' activities. A big step forward is to see the company as a product, which can be subjected to analysis, permanent improvements but also major changes.

An Enterprise Architecture (EA) is a framework that allows analysis, design, planning, and implementation of all aspects of a company, in a holistic manner, at any time in the life cycle of the company, in order to successfully fulfil the mission, objectives and company

${ }^{*}$ Corresponding author: livia.beju@,ulbsibiu.ro 
strategies to achieve better business performance. An Enterprise Architecture contains the organizing logic for business processes and IT infrastructure.

An enterprise developed on the basis of an Enterprise Architecture framework, will operate coherently at all levels and will allow the acquisition of competitive advantages. Its operating structure can be improved or changed in accordance with the life cycle of the business. An enterprise can be a corporation, part of a corporation or a government agency.

This paper aims to analyse how Kanban systems, widely used in today's companies, are integrated into the more comprehensive system of the companies.

\section{Informational models of the enterprises. State of the art}

Enterprise organization models have been developed since the 1990s. The main models are presented below.

The first architecture developed in the 90's was Computer Integrated Manufacturing Open System Architecture (CIMOSA) [1]. This architecture defined a framework structure (CIMOSA cube) that allows enterprises modelling and the integration of all its dimensions.

A reference model of Enterprise Architecture that has a major impact on current enterprise modelling is Purdue Enterprise Reference Architecture (PERA) [2]. The enterprise can be modelled by multiple layers and in multiple stages of the architectural life cycle. PERA levels for business integration are presented in figure 1 . These levels represent a basic tool in current business modelling.

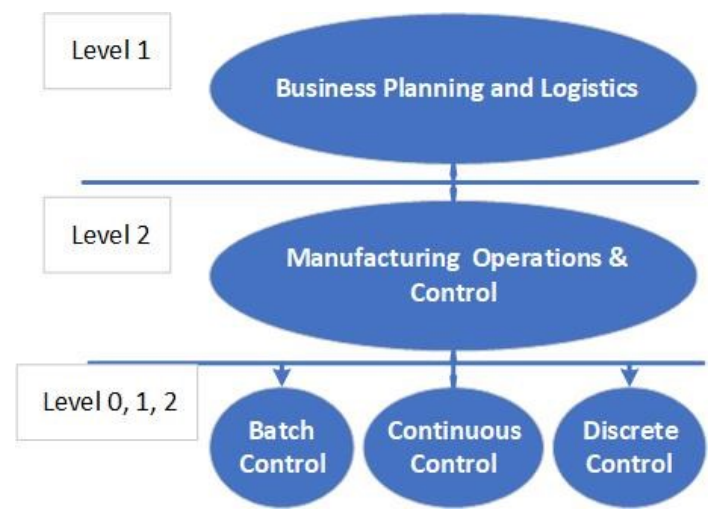

Fig. 1. PERA Reference model. Levels of decision-making and control hierarchy [2].

The GRAI method, (GRAI is short for Graphs with Results and Inter-related Actions) is a modelling method of the enterprise, which allows modelling the decision-making systems of the company $[3,4]$.

Generalized Enterprise Reference Architecture and Methodology (GERAM) is a generalized framework for enterprise integration and business process engineering [5]. It identifies the set of components recommended for use in enterprise engineering. The component that allows the modelling of the enterprise and implicitly of the Kanban systems is the Generic Enterprise Reference Architecture (GERA). Modelling languages are described Generic Enterprise Modelling Languages (GEML). This architecture has been standardized in, "Requirements for Generalized Enterprise Reference Architectures and Methodologies" (ISO15704, 2000).

The most used framework for enterprise architecture today is The Open Group Architecture Framework (TOGAF). It was developed starting with 1995 by The Open Group, 
based on the United States Department of Defence's TAFIM and Capgemini's Integrated Architecture Framework (IAF) [7]. It offers a modularized approach, with a high level of generality, that allows analysis, design, implementation, tracking and improvement of corporate structures. It contains standards and methods of communication among enterprise architecture professionals. The TOGAF Architecture model is divided into 7 parts [8]. The core of TOGAF is The Architecture Development Method (ADM) which describes a method for developing and managing the lifecycle of enterprise architecture. It is graphically represented by a circle with 8 phases [9]. Each phase contains steps that must be followed in order to develop the architecture. It provides a tested and repeatable process for developing architectures [9].

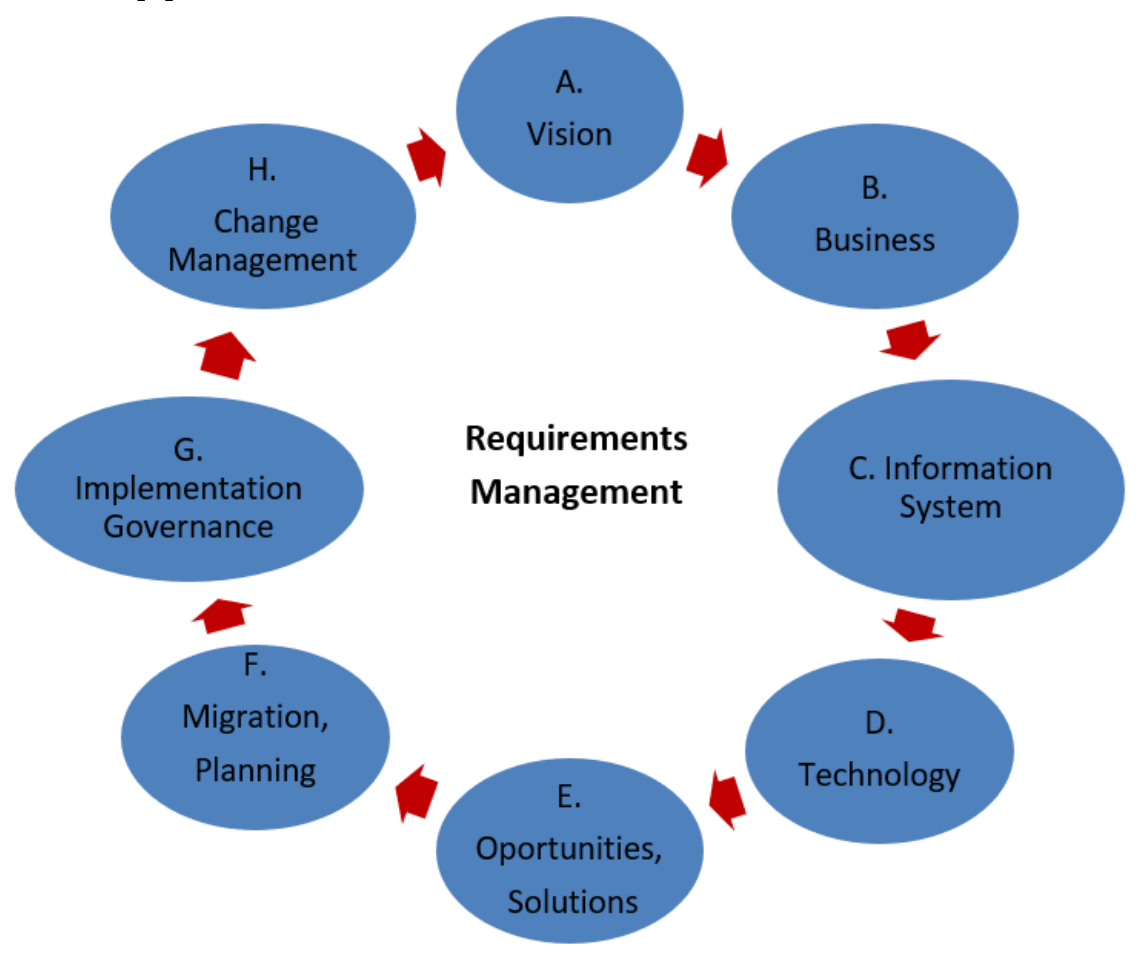

Fig. 2. The phases of the TOGAF Architecture Development Method [9].

We are interested in analysing the Business architecture (phase B) of the TOGAF architecture to understand how Kanban systems are designed in the broader context of the company. The most important business application modules are presented in the literature $[10,11]$. For this analysis we are interested in the modules: Supply Chain Management, Enterprise Resource Planning (ERP) applications, Manufacturing Execution Systems and Manufacturing Process Engineering.

A widely used standard in all industries and in all kinds of processes, such as batch processes, continuous and repetitive processes is the ANSI / ISA-95 standard. It is an international standard developed by the Instrumentation, Systems, and Automation Society, and the American National Standards Institute (ANSI) that was developed for global manufacturers. The standard is based on the Purdue Reference Model for Computer Integrated Manufacturing and defines the interface between control functions and other enterprise functions [12]. 
The purpose of this standard was to provide operating models that facilitate the interface and integration between ERP system, MES system and Shop floor control systems [13].

The standard defines a hierarchical structure with four levels. A synthesis of the informational levels of an enterprise, in concordance with ISA-95 Standard is presented in table 1.

Level 4 refers to Business Planning and Logistics. This level is supported by the ERP information system which aims to keep under control the financial-accounting activities, management, logistics, sales, production, as well as the management of fixed assets.

Level 3 is the Manufacturing Operations and Control level. The main activities within this level are:

- Production Operations Management - Activities that coordinate, direct, manage and track the raw materials, energy, equipment, personnel and information to produce products;

- Inventory Operation Management - Activities that coordinate, direct, manage and track the inventories of products and / or materials and their movements;

- Quality Operation Management - Activities that coordinate, direct, manage and track the measure and report of the quality;

- Maintenance Operations Management - Activities that coordinate, direct, manage and track the maintenance of equipment, tools, and related assets to ensure their availability for manufacturing.

The main flows that are established between levels 3 and 4 are [14]:

- Resource information - materials definition and properties, materials inventory, personnel, equipment, physical asset;

- Operations capability information - What is available to us;

- Operations definition information - How to make a product;

- Operations schedule - What to make and what to use;

- Operations performance - What was made and what was used.

Level 2 corresponds to the process control, level 1 to the sensors and actuators, and level 0 is the production process itself.

The ISA-95 standard also presents a functional and control model of the company. The standard describes the flows required for an efficient planning model [14].

It is important to emphasize that the standard does not intend to dictate exactly the structure of a system, but only outlines some guidelines. There may be variations due to the nature of the products and processes performed by the company [15].

Manufacturing execution system is an information system that connects the top-level information systems (also called enterprise resource planning (ERP), and the lower level (automation systems). MES connects, monitors and controls complex manufacturing systems and data. MES allows the optimization of the manufacturing process as a whole or in real time. With the support of MES, complete information can be provided, that can help the production department to ensure effective execution of manufacturing operations, improve production output and maintain the quality of its products in the long term and with lower costs [16].

MES sustain the entire activity that takes place throughout the life cycle of the manufacturing process from the launch of the order to the delivery stage of the finished products. It also follows several flows from the manufacturing process, namely materials, personnel, equipment, support services. It deals with resource scheduling, execution and shipment of orders, production analysis and management of downtime, maintenance, monitoring of overall equipment efficiency (OEE), product quality, process traceability, etc.

These data allow decision makers to understand the current state of the enterprise and better optimize the production process [17].

Although the benefits of using MES have been mentioned in some studies, not much research has been done on how to effectively implement MES. 
Table 1. Activity model of a manufacturing enterprise - synthesis based on ISA 95 standard.

\begin{tabular}{|c|c|c|c|c|c|c|}
\hline \multirow{3}{*}{$\begin{array}{l}\text { Level } \\
4\end{array}$} & \multirow{2}{*}{\multicolumn{3}{|c|}{ Business Planning and Logistics }} & $\begin{array}{l}\text { - Establish the basic } \\
\text { plant schedule - } \\
\text { production, material }\end{array}$ & $\begin{array}{l}\text { Enterprise } \\
\text { IT } \\
\text { systems }\end{array}$ & Standard \\
\hline & & & & $\begin{array}{l}\text { shipping } \\
\text { - Determining the } \\
\text { inventory level } \\
\text { - Time frame: month, } \\
\text { weeks, days }\end{array}$ & ERP & \\
\hline & $\begin{array}{l}\text { Production } \\
\text { Capability } \\
\text { Information }\end{array}$ & $\begin{array}{l}\text { Production } \\
\text { Definition } \\
\text { Information }\end{array}$ & $\begin{array}{l}\text { Production } \\
\text { Information }\end{array}$ & $\begin{array}{l}\text { Interface between } \\
\text { level } 4 \text { and level } 3\end{array}$ & & $\begin{array}{l}\text { ISA } 95 \\
\text { Part } 1,2\end{array}$ \\
\hline \multirow[t]{2}{*}{$\begin{array}{l}\text { Level } \\
3\end{array}$} & \multicolumn{3}{|c|}{ Manufacturing Execution System (MES) } & $\begin{array}{l}\text { - Manufacturing } \\
\text { operations and } \\
\text { control } \\
\text { - Area supervision, } \\
\text { Production, } \\
\text { Scheduling, } \\
\text { Reability, Assurance, } \\
\text { - Work flow/recipe } \\
\text { control to produce the } \\
\text { desired end products. } \\
\text { - Maintaining records } \\
\text { and optimizing the } \\
\text { production process } \\
\text { - Time frame: days, } \\
\text { shifts, hours, minutes, } \\
\text { seconds }\end{array}$ & MES & $\begin{array}{l}\text { ISA } 95 \\
\text { part } 3\end{array}$ \\
\hline & & & & Interface & & $\begin{array}{l}\text { OPC, } \\
\text { OMAC }\end{array}$ \\
\hline $\begin{array}{c}\text { Level } \\
2\end{array}$ & \multirow[t]{2}{*}{$\begin{array}{l}\text { Batch } \\
\text { control }\end{array}$} & \multirow[t]{2}{*}{$\begin{array}{l}\text { Continuous } \\
\text { control }\end{array}$} & \multirow[t]{2}{*}{$\begin{array}{l}\text { Discrete } \\
\text { control }\end{array}$} & $\begin{array}{l}\text { - Monitoring, } \\
\text { supervisory control } \\
\text { and automated } \\
\text { control of the } \\
\text { production process } \\
\text { Time frame: minutes, } \\
\text { seconds }\end{array}$ & \multirow[t]{2}{*}{$\begin{array}{c}\text { Shop floor } \\
\text { control } \\
\text { systems } \\
\text { PLC } \\
\text { SCADA }\end{array}$} & \multirow{2}{*}{$\begin{array}{c}\text { ISA 88 } \\
\text { (Batch } \\
\text { Control) }\end{array}$} \\
\hline $\begin{array}{c}\text { Level } \\
1\end{array}$ & & & & $\begin{array}{l}\text { - Sensing the } \\
\text { production process, } \\
\text { manipulating the } \\
\text { production process }\end{array}$ & & \\
\hline $\begin{array}{c}\text { Level } \\
0\end{array}$ & \multicolumn{3}{|c|}{ Material flow } & $\begin{array}{l}\text { The actual production } \\
\text { process }\end{array}$ & & \\
\hline
\end{tabular}

ERP (Enterprise Resource Planning)

MES (Manufacturing Execution System)

OMAC (The Organization for Machine and Control)

OPC (Object Process Control) Unified Architecture is a machine-to-machine communication protocol

PLC (Programmable Logic Control)

SCADA (Supervisory Control and Data Acquisition) 
The analysis of production and supply flows was presented by Wagner [18] who developed an informational flow model.

Companies have implemented various information systems, more or less complex, depending on the nature and amplitude of the production, the industrial area, the existing competition on the market, the stability of the relations with the customers and respectively with the suppliers.

Most companies have implemented IT products for level 4. Level 3 of the company's organization can be fully or partially supported by current IT models. As for connections with levels 2,1 , and 0 , they may or may not be supported by IT systems. In many situations there are only islands with coordination through IT systems.

However, in the actual literature, it is not described how Kanban systems are inserted between production and supply flows, on the production lines.

\section{Kanban systems in the context of organizations systems}

Nowadays, most companies have flow production processes. This way of organizing the production was first developed and used by Toyota Company. The Toyota manufacturing system was the one that marked the transition from the mass manufacturing system to the one organized on manufacturing flows [19]. The Toyota system is focused on reducing wastes in the production process. Just in time and Jidoka are the two main pillars of this manufacturing system which allows less work in progress (WIP) and better quality of the products.

The continuous flows that work without overproductions and with small inventories can be obtained only with Kanban system implementation [20].

The Kanban system refers to the frequent supply of small stocks, either by triggering upstream production processes or by triggering supply from other inventories [21].

Kanban systems are currently applied in all industries and in all types of companies.

The size of the company, the industry in which it operates, its technological level and the role it plays on the market determine the level of the company IT system.

Starting from the organizational structure of the company and especially from its level of computerization, we can describe three distinct ways of organizing Kanban systems. These are:

- Enterprise with a high degree of computerization, with level 3 of the company's organization (MES) fully supported by IT systems, which completely manages both the supply flows and the production flows, can efficiently organize and optimize a push production. In this situation, the production is triggered by documents transmitted electronically upstream of the production flows. This kind of companies organizes only Kanban supply system (fig.3).

- Companies that, although they have a well-developed IT system at ERP level (level no.4), are important players in the market, and have long-term partnerships with both customers and suppliers, choose to implement pull production flows through the Kanban production system. The start of production is done through the Kanban board. These companies organize both Kanban production systems and Kanban supply systems (fig.4).

- Companies that have long-term partnerships with both customers and suppliers, and do not invest in complex IT systems for the company's third level of organization (MES), can organize production Kanban systems as well as supply Kanban systems. In this situation, the production is triggered by the rhythm of deliveries to the customers (fig.5).

The paper develops several variants of organizing Kanban systems in the broader context of different ways of organizing the business.

The description of the Kanban systems was made in the graphic language of the Value Stream Map (VSM). 


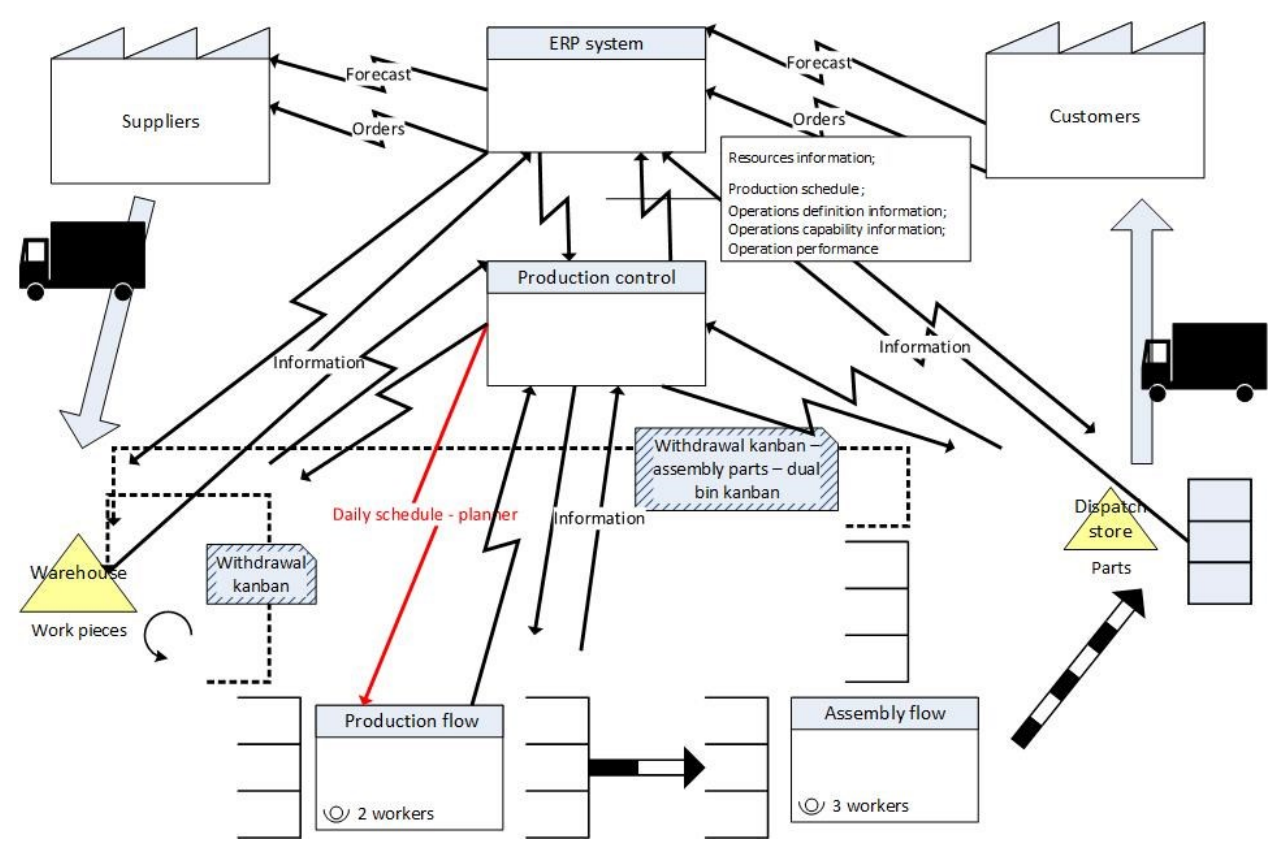

Fig. 3. Push production with withdrawal Kanban.

A successful organization model is one in which the company has a well-developed IT system at all levels (fig3). The company has a complete ERP system. The most used ERP system nowadays is the SAP computer system. There is also a complete computer system for MOM / MES production management, specific to that company. It is also possible to have a certain level (total or partial) of computerization at levels 1 and 2 (ISA 88), respectively the connection with level 3 of the ISA 95 architecture. In this case a push type production system is organized.

The production launch documents will be the ones that order the products fabrication starting from the upstream flow (in our case it is a fabrication flow) and continues with the downstream one (in our case it is an assembly flow). The performance of the information system as a whole allows the optimization of all production and material flows. In this situation the Kanban supply system is used only for the materials supply in the supermarket inventories on the production lines and the minimization of work in progress (WIP).

Other companies have well-structured and complex ERP systems, but the MES IT systems are not fully developed. In this situation, at the level of production management, a complete Kanban system (both production and supply) is extremely efficient. Production is triggered through the Kanban board. If the company has managed to build long-term partnerships with both beneficiaries and suppliers, it will also be able to implement production levelling (Heijunka). The production planner will put cards on the Kanban Heijunka board, every morning. These will trigger the production system. Figure 4 shows a dual Kanban system fully triggered by the Kanban Heijunka board. 


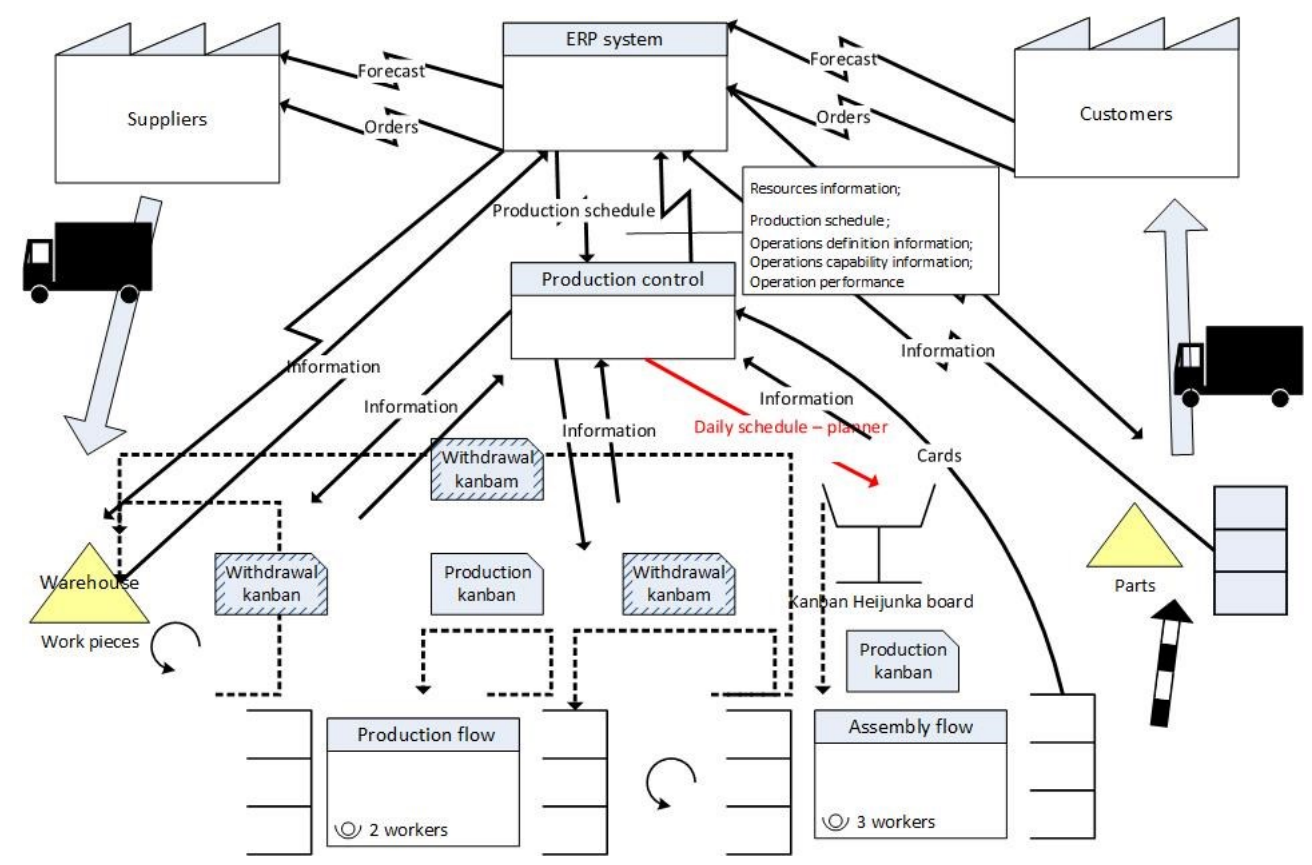

Fig.4. Pull production with withdrawal Kanban and production Kanban triggered by Kanban board.

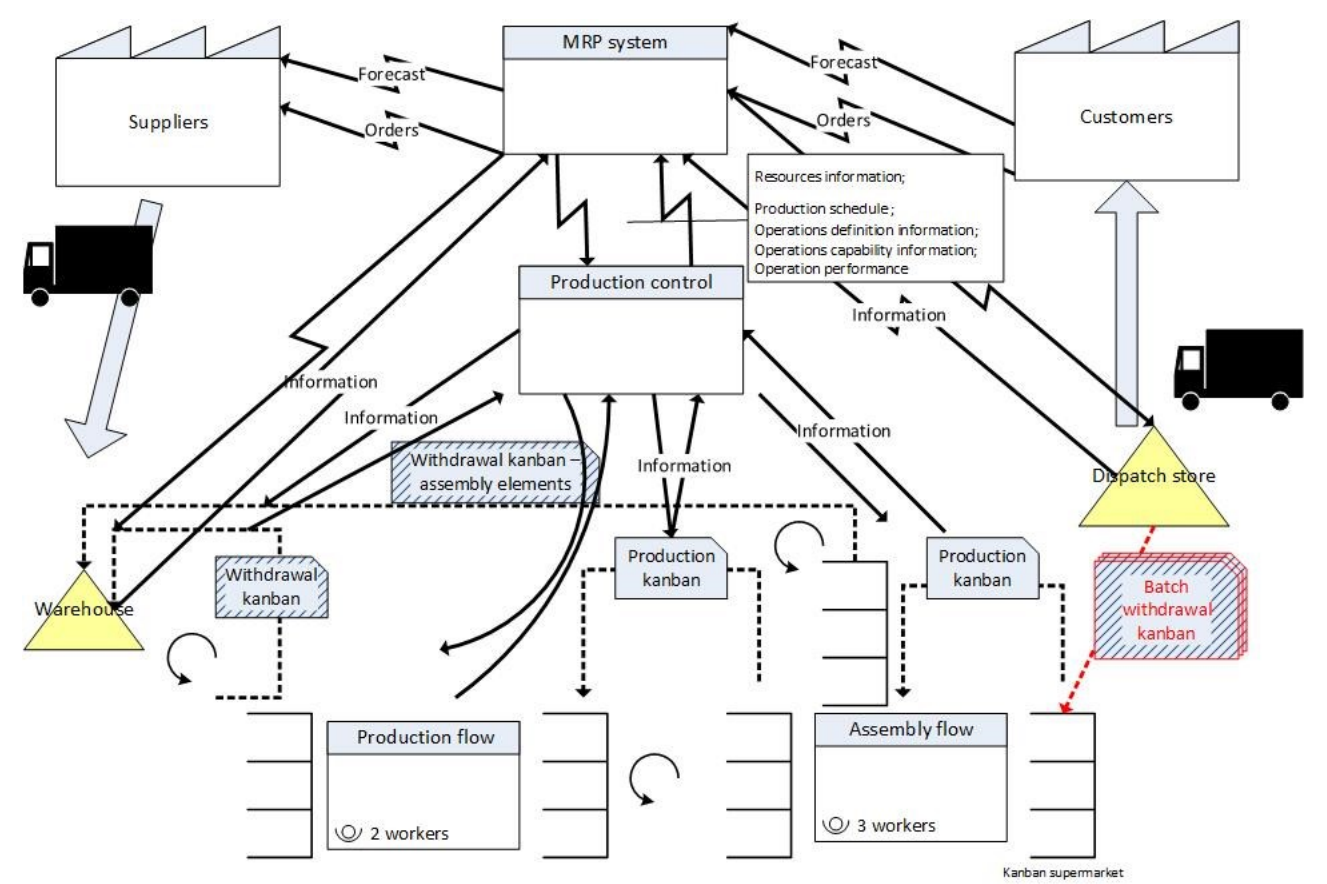

Fig. 5. Pull production with withdrawal Kanban and production Kanban triggered by the dispatch to the customers. 
Organizations with a lower level of computerization, which have developed stable partnerships with customers and suppliers, can organize Kanban systems like the ones shown in figure 5. Parts of established products categories are produced daily. Customers take daily products from the dispatch store. As each container is associated with a card, once the products are delivered, the cards (taken from containers) are collected and will command production on the assembly line, in order to refill de stock. Dual Kanban is presented in figure 5, which contains both production Kanban and withdrawal Kanban.

Each type of production organisation presented in figures 3, 4 and 5 requires information flows that can be managed by a computer system, by physical documents, even oral information, or combinations of them, depending on the management structures developed by each company.

Companies with a good position in the market and those who want to obtain a competitive advantage are those that are willing to invest in complex management IT systems, and to develop themselves in accordance with the reference architectures. This approach will allow the company to have a greater flexibility, to quickly change production and managerial structure in concordance to the new requirements on the market.

For this approach it is important to understand the current managerial structure of the company, to model the internal flows, and then to develop generic and particular architectures, in accordance with existing Enterprise Reference Architectures, standardized nowadays. For the manufacturing industry, flow modelling can be done using GRAI models, UML languages and VSM symbols. ISA-95 and ISA 88 standards support functional and control modelling of the company.

The development of reference architectures can start from the TOGAF architecture by using Architecture Development Method part, Phase B: Business Architecture developing methodologies.

\section{Conclusion}

The paper aims to describe the Kanban systems, in a broader overview of the company's flow modelling. Such an analysis seeks to link the approach of systemic description of the company with the approach of improving the companies' activities.

The analysed architectures were, PERA, GERAM and TOGAF. In this analysis, the focus was on those parts of the architectures that allow modelling the internal flows of the enterprises.

In the case of the PERA architecture, the useful structures for our analysis were the levels for business integration.

When using the GERAM architecture, the modules of interest are GERA (Generic Enterprise Reference Architecture) and GEML (Generic Enterprise Modelling Languages) with the ULM (Unified Modelling Languages).

When using architecture TOGAF, enterprise flows can be modelled and studied using Architecture Development Method, Phase B: Business Architecture, with the modules Supply Chain Management, Enterprise Resource Planning (ERP) applications, Manufacturing Execution Systems and Manufacturing Process Engineering.

The synthesis of the ANSI / ISA-95 standard allowed the development of a coherent framework for the analysis of information flows at the company level. The framework was a basis for integrating Kanban systems into the company's broader systems. Levels 3 and 4 of the ISA-95 models, respectively ERP (Enterprise Resource Planning) and MES (Manufacturing Execution System) were analysed in more detailed way, to be able to insert Kanban systems in a coherent way in the enterprise flows system. 
Starting from the organizational structure of the company and especially from its level of computerization, the paper described three distinct ways of organizing Kanban systems. These are:

- Push production with withdrawal Kanban used by enterprises with complex IT system, which completely manages both the supply flows and the production flows. Production is triggered by documents transmitted electronically to the upstream production flows. Only withdrawal Kanban is used.

- Pull production with withdrawal Kanban and production Kanban triggered by Kanban board used by companies that, although they have a well-developed ERP system, the MES system it's not complete developed. Both Production Kanban and withdrawal Kanban are used. Production is triggered by cards from the Kanban Heijunka board.

- Pull production with withdrawal Kanban and production Kanban triggered by the dispatch to the customers are used by companies that have long-term partnerships with both customers and suppliers and do not invest in complex IT systems, for the company's third level of organization (MES). Both Kanban systems are used. In this situation, the production is triggered by the rhythm of deliveries to the customers.

Finally, some indications for using the analysed models for the improvement of both the structure of the companies and the flows activities are specified.

\section{References}

1. E. Latiffianti, N. Siswanto, S. E. Wiratno, Y. A. Saputra, AIP Conference Proceedings 1902, 020040 (2017).

2. T.Williams, Computers in Industry, 24, Issues 2-3, 41 (1994)

3. D. Chen, B. Vallespir, G. Doumeingts, Computers in Industry, 33, Issues 2-3, 387 (1997)

4. G. Doumeingts \&Y. Ducq, Production Planning \& Control, The Management of Operations, 12, Issue 2, 14 (2001)

5. P. Bernus, O. Noran, A.Molina, Enterprise Architecture: Twenty Years of the GERAM Framework, Annual Reviews in Control, 39, 83 (2015)

6. https://en.wikipedia.org/wiki/Generalised_Enterprise_Reference_Architecture_and_Me thodology

7. J.A.Camatti, G.M. Rabelo, M Borsato, Procedia Manufacturing 51, 1132 (2020)

8. http://www.togaf.info/togaf8/togafSlides/TOGAF-V8-M3-Intro-ADM.PDF

9. https://www.visual-paradigm.com/guide/togaf

10. https://systemarchitect.info/togaf/togaf-9-2-metamodel/

11. http://iea.wikidot.com

12. http:/www.isa.org

13. L. F. McGinnis, Formalizing ISA-95 Level 3 Control with Smart Manufacturing System Models (U.S. Department of Commerce Engineering Laboratory - Systems Integration Division National Institute of Standards and Technology Gaithersburg, 2019)

14. A. Lundius, Initial Assessment of Manufacturing, Execution Systems, Development of a methodology to define business needs and functional requirements, (Royal Institute of Technology Stockholm, 2019)

15. M.Brandl, MESA International, Practical Applications of the ISA 95 standard

16. R. Qiu, M. Zhou, Engineering, Computer Science, IEEE Robotics \& Automation Magazine, 11, 19 (2004) 
17. R. Govindaraju, K. Putra iMEC-APCOMS, IOP Conf. Series: Materials Science and Engineering, 114 (2016)

18. B. Wagner, M. Strobel, Flow Management for Manufacturing Companies. Sustainable Re-organization of Material and Information Flows, imu augsburg GmbH \& Co. KG, Augsburg, Germany (2003)

19. M. Apreutesei, E. Suciu, I.R. Arvinte, Analele Universitatii "Eftimie Murgu" Resita, Year XVII, 2, 23 (2010)

20. A. Krishnamurthy, R. Suri, M. Vernon, The International Journal of Flexible Manufacturing Systems, 16, 123 (2004)

21. J. Matzka, · M. Di Mascolo · K. Furmans, J. Intell. Manuf., 23, 49 (2012) 